\title{
DOES RELIGIOUS FREEDOM WARRANT PROTECTION AS A FUNDAMENTAL HUMAN RIGHT?
}

Frane STANIČIĆ

Faculty of Law, Zagreb

UDK: 342.731

Izvorni znanstveni rad

Primljeno: 7. 3. 2018.

Religious freedom is, in various legal documents, stipulated as a fundamental legal right. The European Convention on Human Rights prescribes that everyone has the right to freedom of thought, conscience and religion. When we glance through the constitutions of countries of western legal order, we find that most of them prescribe freedom of religion as a fundamental right. However, there are authors who argue that freedom of religion does not warrant protection by a special right. Their principal argument is that the right to freedom of religion can be derived from more basic rights, and that this right should be protected as a right derived from such rights. The aim of this paper is to determine whether freedom of religion merits protection as a fundamental legal right or should it be protected as a derived right in which case it should be protected while protecting other fundamental rights such as the right to freedom of thought or conscience.

Keywords: freedom of religion, fundamental right, derived right, legal protection

Frane Staničić, University of Zagreb, Faculty of Law, Trg Republike Hrvatske 14, 10000 Zagreb, Croatia. E-mail: frane.stanicic@pravo.hr

Freedom of religion (FoR) is enshrined, in various legal documents, as a fundamental legal right. The European Convention on Human rights prescribes that everyone has the right to freedom of thought, conscience and religion. When we glance 
DRUŠ. ISTRAŽ. ZAGREB GOD. 28 (2019), BR. 2, STR. 189-206

STANIČIĆ, F: DOES RELIGIOUS... through constitutions of countries of western legal order, we find that most of them prescribe freedom of religion as a fundamental right.

However, there are authors who argue that freedom of religion does not warrant protection by a special right. Their principal argument is that the right to FoR can be derived from other, more basic rights, and that this right should be protected as a right derived from such rights (Sapir \& Statman, 2005; Himma, 2014; Leiter, 2008, 2013). Furthermore, the question of whether or not there should be a human right to FoR is debated in various papers (Smith, 1991; Tiedemann, 2015).

The aim of this paper is to determine whether freedom of religion merits protection as a fundamental legal right or should it be protected as a derived right in which case it should be protected while protecting other fundamental rights such as the right to freedom of thought or conscience. It represents a theoretical analysis which combines the use of philosophy of religion and legal science in order to illustrate how the questions of fundamental religious freedoms are dealt with in practice. First, I argue that FoR is a fundamental legal right. In the second part of the paper I present principle arguments contra and pro FoR as a FHR. The Discussion presents the main part of the paper in which I argue that FoR is a FHR, and that it cannot be derived from other FHRs.

\section{Freedom of religion as a fundamental legal right}

Religion has been designated as "the third great unifier of humankind, alongside money and empires" (Harari, 2014, p. 365). That is why there are many international legal documents on FoR. They have established a certain set of rules regarding FoR. One is entitled to manifest one's religion or belief. This means that religious teaching, including proselytism, is protected by FoR as has been confirmed by the European Court of Human Rights (ECtHR) (Kokkinakis v. Greece, 1993) which found that freedom of thought, conscience and religion is "one of the foundations of a democratic society. This freedom, in its religious dimension, is one of the most important elements that create the identity of believers and their conception of life, but it is also a precious tool of atheists, agnostics, sceptics and those who do not have any relation towards faith". This stance of the ECtHR was most vividly stressed in the 2011 Bayatyan judgement in which the ECtHR reiterated its doctrine under which the state must obtain the "role of a neutral and impartial organiser of expression of various religions, beliefs, and convictions, thereby contributing to public order, religious harmony and tolerance in a democratic society". Furthermore, FoR has its "mirror image" right that is not for- 
DRUŠ. ISTRAŽ. ZAGREB GOD. 28 (2019), BR. 2, STR. 189-206

STANIČIĆ, F: DOES RELIGIOUS.. be free from religion. It is truly difficult to think of any other "freedom-right" that has an "anti-right" of this nature associated with it in quite this fashion (Evans, 2014, p. 532).

"The contemporary understanding of religious liberties differentiates between three basic principles:

1) freedom of religious belief, which is considered absolute,

2) freedom of religious practice, which is subject to various limitations ... and

3) nondiscrimination on the basis of religion" (Strong, 2015, p. 837).

It is considered that freedom of belief, as an absolute right, "is the most important aspect of religious liberty", and that its protection "has shifted over time from 'mere' toleration of diverse religious beliefs to a legal right" (Strong, 2015, pp. 847-848). The other two aspects are also important, but cannot exist without the freedom of religious belief. Since freedom of religious belief is absolute, the State does not have the right to force anyone to participate in religious practices. Furthermore, religious belief includes belonging to a religion. This means that we as people are free to choose whether or not we want to belong to a religion (religious belief). One's choice must not have negative consequences.

It is important to note that FoR is recognised not only as a legal right, but also as a moral right. I will use Sparer's definition of inalienable FHR to show what I believe to be a "fundamental right". "... certain fundamental human rights are inalienable. They exist regardless of whether or not they have been legally recognized. These rights ... including the right to free religious expression; ... are part of ourselves as human beings, ... But certain fundamental human rights are inalienable, regardless of the arguments for legal recognition .... These rights are part of our potential, what we might be as living persons, ... We cannot give these rights away ... any more than we can give away a part of ourselves. We certainly can deny them to ourselves and to others. But when we do, we deny a part of ourselves and a part of others. We can act as if these rights do not exist; ... if we stop expressing these parts of our humanity, we become 'alienated' ... We would be suppressing a piece of ourselves or acceding to the efforts of others to suppress us" (Sparer, 1984, pp. 512-513).

\section{Principal arguments contra freedom of religion as a fundamental right}

As Dworkin puts it, "arguments from text, history, and policy are inadequate to justify a basic [constitutional] right" (Dworkin, 2013, p. 111). The main idea is that, regardless of whether or not it is considered "normal" to think of FoR as a FHR, it is not enough to base one's argument in favour of this contention 
DRUŠ. ISTRAŽ. ZAGREB GOD. 28 (2019), BR. 2, STR. 189-206

STANIČIĆ, F: DOES RELIGIOUS... on the fact that this is written in constitutions or various legal documents. Dworkin states that we must find a "principled justification for offering religion a right to special protection that is exclusive to theistic religions" (Dworkin, 2013, p. 117), which he finds "difficult, if not impossible" (Dworkin, 2013, pp. 110-116). FoR should be treated as a very general right to what we might call "ethical independence", but the government may limit that right for many other reasons, such as "to protect other from harm, or to protect natural wonders, or to improve general welfare" (Dworkin, 2013, pp. 130-131).

Sapir and Statman found that FoR can be justified as a separate category only if religion is considered worthy of special protection. However, awarding it a "separate status gives a religious conscientious clamant an advantage that does not sit well with the principle of equality". The problem is that if "law is concerned for the conscience of all people, then it respects all cultures and cannot award the religious conscience or culture a special status" (Sapir \& Statman, 2005, p. 486). If we accept the idea of equality, it is impossible to grant FoR, "whether we take it as a branch of freedom of conscience or a branch of the right to culture, a special status within the framework of these rights" (Sapir \& Statman, 2005, p. 487). In this respect, special protection of FoR violates the principle of neutrality toward religion as it should be protected under other rights.

Leiter stated that "there is no principled reason for legal or constitutional regimes to single out religion for protection; there is no moral or epistemic consideration that favours special legal solicitude towards beliefs that conjoin categorical commands with insulation from evidence" (Leiter, 2008, p. 26). Recently, Chiassoni stated that "special status" of FoR should be dismissed because "that is, indeed, a must for any coherent supporter of the constitutional state and liberal liberty of conscience" (Chiassoni, 2016, p. 30). Also, Chiassoni finds that, "unfortunately for theistic believers, however, from the standpoint of liberalism - the backbone axiology of the constitutional state - 'arguments pro the FoR' are by no means conclusive. In fact, they can be easily turned down." (Chiassoni, 2016, p. 31).

It is also said that states should not privilege religion over other ethical or moral codes "because religious beliefs are not the only beliefs that are strongly held and integral to a person's identity". Why would it then be appropriate to prefer one type of belief over other belief systems? Another issue is the fact that "focusing on religion per se primarily benefits organised faiths while ignoring more individualized belief systems" (Strong, 2015, p. 880, 881). Another objection to FoR is 
DRUŠ. ISTRAŽ. ZAGREB GOD. 28 (2019), BR. 2, STR. $189-206$

STANIČIĆ, F: DOES RELIGIOUS.. that it allows for a sharp conflict between religious liberties and secular society, and that is why limits are necessary (Strong, 2015, p. 883; Strong, 2017, p. 84). For example, non-religious persons may feel insulted or uncomfortable if there is a visible religious symbol in educational or business premises.

Maybe the strongest objection is that FoR should not warrant protection as a FHR because it is a derived right. This means that it can be derived from or to say it better, protected by more basic FHRs. Therefore, FoR can make sense as a FHR only if it is not embraced by more widely framed freedoms, such as freedom of conscience, freedom of thoughts, free speech and free association (Tiedemann, 2015; Himma, 2014).

FoR can be seen as threefold - freedom of religious thought, freedom of religious practice and freedom from religious discrimination. Tiedemann finds that "freedom of religious thoughts and religious speech are embraced by the general human rights of freedom of thoughts and freedom of speech, and the right not to be forced to act contrary to religiously founded moral rules is embraced by the general human right to freedom of conscience." He finds that we have to recognise a human right to freedom of religious rites (Tiedemann, 2015, p. $83)$, therefore narrowing the FoR into one of its components - the right to perform religious rites.

Himma finds that FoR doesn't warrant special protection as a FHR as it is a fully derived right. In his opinion, it can be deduced from constitutional rights protecting free speech, thought, autonomy, conscience, and association. In Himma's words, "in order to justify protecting an interest with a special right to $X$, two conditions must be satisfied: (1) the relevant interest must arise uniquely from $X ;(2)$ the relevant interest must reach a certain level of value (i.e. must be sufficiently important); and (3) we must have some plausible reason to think that the relevant interest can actually be threatened by something in the world." (Himma, 2014, pp. 39-40).

One of Himma's principal arguments is that we have no reason to believe that any unique special interests of religious people can truly be harmed as it cannot be proved that God exists. If the existence of God cannot be proven, there cannot be any kind of punishment for actions that are contrary to religious beliefs - interests cannot be threatened. Even if we disregard this argument, Himma argues that "interests in free speech, belief, association and conscience warrant protection by the corresponding constitutional rights" (Himma, 2014, p. 40). Of course, Himma doesn't argue that FoR doesn't warrant any protection - he argues that it doesn't warrant protection of a special constitutional right. In his view, it can be protected by a statutory right (Himma, 2014, p. 34). 


\section{Principal arguments pro the freedom of religion as a fundamental right}

According to some authors (Sapir \& Statman 2005, p. 470) four justifications for the special protection of religion come to mind regarding the effect of violation of FoR:

1) it has a negative moral effect on society,

2) it has a negative effect on the average level of happiness,

3) it is a severe blow to the conscience and to the integrity of the religious individual,

4) it weakens religious culture.

Other authors find slightly different justifications for supporting religious liberty:

1) promotes civil peace,

2) minimises alienation,

3) furthers personal autonomy,

4) liberty promotes self-definition,

5) furthers the search for truth (Strong, 2015, p. 861).

Religious liberty leads to unity in a society, enhances peace. It promotes public good (Raz, 1986, pp. 198-199). It follows that interfering in the freedom of religion leads to diminishing peace, antagonises the society and reduces the level of happiness in a society. Interfering with FoR leads to strife in a society and social conflict (Finke, 2013; Grim \& Finke, 2011). Therefore, these authors clearly deduce that FoR should be protected as a FHR.

Ample argumentation pro the freedom of religion as a FHR can be found in the practice of the ECtHR as it has been interpreting the European Convention, especially in the context of our contemporary society (Tulkens, 2014, p. 509). Within its practice, FoR became an essential right of considerable importance (Overview, 2013, p. 1). ECtHR justified its actions by stating that FoR "is one of the foundations of a democratic society. The pluralism indissociable from a democratic society, ... depends on it" (Bayatyan v. Armenia 2011, para. 118), and is "necessary to maintain true religious pluralism, which is vital to the survival of a democratic society" (para. 122, Manoussakis and Others v. Greece 1996, para. 44, Metropolitan Church of Bessarabia and Others v. Moldova 2001, para. 119).

ECtHR firmly established FoR as a FHR, thereby protecting various beliefs, including convictions and philosophies. In this way, ECtHR has achieved protection not only for "traditional and long-established religions ..., but also to other forms of religious movements ... as well as to wide range of philosophical beliefs" (Tulkens, 2014, p. 513). It should be noted that "the history of Europe is littered with examples of extreme religious intolerance and, indeed", the Convention "was conceived in the immediate aftermath of the persecution and genocide of the adherents of one religion, Judaism, in the 
DRUŠ. ISTRAŽ. ZAGREB GOD. 28 (2019), BR. 2, STR. 189-206

STANIČIĆ, F: DOES RELIGIOUS..

\section{DISCUSSION}

hope that it would help to prevent such an atrocity ever taking place again. For many believers, religious faith is central to their existence and their most important defining characteristic." ECtHR justifiably stresses in its jurisprudence "the duty of the State as a guarantor of pluralism and the fundamental nature of the rights to freedom of belief and freedom to manifest religion" (White \& Overy, 2006, pp. 423-424).

I will focus primarily on the "derived right" argument, but I will also critically examine other principal (as I see them) arguments contra the FoR as a FHR: the 'non-existence of God' argument, and the 'breach of equality' argument.

I will use one argument pro the FoR as a FHR which I call the "risk" argument. Because of the fact that FoR constitutes an inalienable right, any violation of that right is prone to cause disturbances, violence and strife in society. This is one of the principal arguments that FoR is and should be protected as a FHR. In the words of Sparer, FoR is a part of our potential, what we might be as living persons.

It should also be explained that one of the main arguments pro the FoR as a FHR which warrants special protection is the fact that FoR can get into conflict with other, indisputably FHRs. If FoR is not a FHR in its own right, then it has a "lower" legal standing in comparison to undisputable FHRs, for example, the right to expression. In case of a clash between FoR and "real" FHRs which are constitutionally protected, such a clash can have only one outcome.

First, I will critically examine the "non-existence of God" argument. It is said that FoR doesn't warrant special protection because it is not possible to show, sufficiently, that interests of believers are threatened on the basis that the existence of God cannot be proved. As Himma puts it, "there is no consensus that any of the arguments for God's existence actually provide some evidence for believing that God exists. ... there is insufficient evidence to believe that God exists. ... there is insufficient evidence that people have an interest in avoiding hell that can actually be threatened in a manner that warrants legal protection by a special fundamental right" (Himma, 2014 , p. 32). Himma does not stand on the position that FoR should not be protected at all, but argues that it is sufficiently protected by other FHRs.

Religious beliefs belong to fundamental convictions (according to Dent as quoted in Sapir \& Statman, 2005, p. 475) "through which their holders retain a sense of their moral integrity and decency as people". As ECtHR puts it, religious and philosophical beliefs concern individuals' attitudes towards religion, an area in which even subjective perceptions may be important (Mansur Yalçın and Others v. Turkey 
DRUŠ. ISTRAŽ. ZAGREB GOD. 28 (2019), BR. 2, STR. 189-206

STANIČIĆ, F: DOES RELIGIOUS...
2014, para. 70). The State's duty of neutrality and impartiality is incompatible with any power on the State's part to assess the legitimacy of religious beliefs or the ways in which those beliefs are expressed (Manoussakis and Others v. Greece, para. 47, Hasan and Chaush v. Bulgaria, 2000, para. 78; and Fernández Martinez v. Spain, 2014, para. 129) or to dictate which beliefs are valid and which are not.

Religious convictions are so important to people that we can observe them as a part of their identity. FoR is a universal value since we all feel the wrongness in making someone change his or her religion or suffer the loss of a right. I find this not to be so with all other convictions. Namely, researchers have shown that, for example, in India, the failure to protect minority religions has resulted in restrictions being imposed by other groups as well as periodic violence resulting from attempts to impose or resist such restrictions (Finke, 2013, p. 304).

Another reason why I argue that the "non-existence of God" argument is not valid is that it disregards non-theistic religions. Some religions, such as Buddhism, Daoism or Confucianism are characterised by their disregard of gods. "These creeds maintained that the superhuman order governing the world is the product of natural laws rather than of divine wills and whims" (Harari, 2014, p. 204). For example, in the teachings of Siddhartha Gautama, "suffering arises from craving; the only way to be fully liberated from suffering is to be fully liberated from craving; and the only way to be liberated from craving is to train the mind to experience reality as it is" (Harari, 2014, p. 395). Therefore, for such a religion, the existence or non-existence of God is irrelevant, which is why this argument falls short from proving that, because God doesn't exist, FoR does not deserve special status, although one could argue that such religions could be protected by the right to freedom of conscience. However, I will show that that is not the case.

The claim that giving FoR a special status does not sit well with the principle of equality is a claim often made in literature (for references see Horwitz, 2014, pp. 1228-1229). Rawls states that "the state can favor no particular religion and no penalties or disabilities may be attached to any religious affiliation or lack thereof. The notion of a confessional state is rejected. The law protects the right of sanctuary in the sense that apostasy is not recognized, much less penalized, as a legal offense, any more than is having no religion at all. In these ways the state upholds moral and religious liberty. ... the state must be understood as the association consisting of equal citizens. It does not concern itself with philosophical and religious doctrine but regulates individuals' pursuit of their moral and spiritual interests in accordance with princi- 
DRUŠ, ISTRAŽ ZAGREB GOD. 28 (2019), BR. 2, STR. 189-206

STANIČIĆ, F. DOES RELIGIOUS.. ples to which they themselves would agree in an initial situation of equality" (Rawls, 1999, p. 186).

Other authors have seen this as a trend toward radical "secular egalitarianism" that threatens religious freedom as we know it (Smith, 2014). It was also pointed out that "the traditional liberal conception according to which a fair society is one in which we all have the same set of rights is only plausible under a certain presupposition, namely that the state is neutral with respect to the interests of different cultural (hereunder religious) groups. The state is assumed - by the traditional liberal egalitarian - to be culturally and religiously blind. The problem according to Kymlicka is that this presupposition is not satisfied in actual multi-cultural and multi-religious liberal societies. Actual liberal states have always implemented policies aimed at bolstering and securing a certain "societal culture". Such policies - what Kymlicka calls "nation-building policies" - have imposed things like a common language, common educational policies, common national symbols, state holidays and national media. ... These policies have implicitly or explicitly reflected the majority culture's symbols, customs and values. The typical liberal state is, thus, in actual fact far from culturally and religiously neutral" (Binderup, 2007, pp. 96, 97).

FoR should not be seen as a danger to equality but as a means to preserve equality (similar in Rawls, 1999, p. 192). As Sapir puts it, FoR can be seen as a "measure aimed to guarantee the survival of minority cultures" (Sapir, 1999, p. 634) by ensuring that they are given equal treatment within the society in which they live. However, he argues that this right must be limited to the instances where the damage to the religious culture is significant and direct, and where the price to be paid by the majority is not high.

It is important also to note that, especially in the jurisprudence of the ECtHR, FoR is not only reserved for religious, theistic beliefs, but also for nontheistic and philosophical convictions. If one argues that granting FoR a special status violates the principle of equality (Sapir \& Statman, 2005), he forgets that this can result in growing conflicts between secular and religious society. For example, how would a situation in which the freedom of press were to inevitably offend religious beliefs on a greater scale be resolved? Or a situation in which, using the FHR to association, the internal organisation of a religious community were to be, against its rules, altered? "Essentially, the argument is that it is unfair - from an egalitarian point of view - that members of minority cultures should incur large costs of assimilation to the societal culture that are not incurred by members of the majority culture. Minority rights are to be seen as compensations for these added costs in the 
DRUŠ. ISTRAŽ. ZAGREB GOD. 28 (2019), BR. 2, STR. 189-206

STANIČIĆ, F: DOES RELIGIOUS... name of equality" (Binderup, 2007, p. 97). The argument then goes that, "since members of minority cultures typically have much less chance of having their "cultural interests" satisfied than members of the majority culture, a liberal state ought to grant minority rights and adopt policies that seek to make actual opportunities more equal" (Binderup, 2007, p. 98).

If we do not attain FoR fundamental status, then any undisputedly FHR prevails in every instance. We can very well see that, while respecting the principle of equality, the state would instigate ever growing conflict between secular and religious society. In essence, in doing so, it would create the situation it was trying to avoid. It is important to note that I am not suggesting that FoR has to have precedence in all instances. If you grant certain rights to religious groups it is possible to antagonise secular society. That is why the balance of interests must be achieved where there is a possibility of a conflict of rights. This goal is not easily reached as it is always difficult to check whether the right balance has been struck (Tulkens, 2014, p. 522). But, in doing so, we are ensuring that an equilibrium between sometimes conflicting rights exists, ensuring the melting down of various conflicts. If granting FoR the status of a special right helps in achieving this goal, then it would warrant it on that basis alone. However, sometimes it is impossible to put various rights in a hierarchy and that is why the aim should be to achieve "mutual concessions" to "delay the inexorable sacrifice until the last" moment, therefore fostering "solutions that preserve the two conflicting rights to the maximum rather than simply finding a point of balance between them" (Tulkens, 2014, p. 526). But, even this path suggests the existence of rights of the same level, or the dilemma would not exist.

The argument contra the FoR as a FHR I find to be most credited is the one that it is a derived right. If that is so, and FoR truly can, in essence, be successfully protected by more basic rights, there really would be no need for protecting it as a FHR. Chiassoni states that the "notion of religious freedom can be made more precise by regarding it as conceptually dependent on two more basic freedoms: freedom of thought and freedom of conscience. Religious freedom can be characterised as the specification of the liberal freedom of thought and the liberal freedom of conscience in relation to religious matters. ... The ontology, epistemology, cosmology, and eschatology of theistic and non-theistic religions are protected by religious freedom as a specification of freedom of thought; the moral, dress, food, ritual and worship codes of theistic and non-theistic religions may be considered as being protected, instead, by religious freedom as a specification of freedom of conscience" (Chiassoni, 2016, p. 30). 
DRUŠ, ISTRAŽ ZAGREB GOD. 28 (2019), BR. 2, STR. 189-206

STANIČIĆ, F: DOES RELIGIOUS..
I will contrast FoR with the a "real" FHR to show whether all aspects of FoR can be truly "covered" by them.

Maybe the hardest to distinguish is the freedom of conscience and FoR. Some argue that it is highly unlikely that any court will extend protection to any belief or practice that "an individual might consider important or valuable, but not obligatory," and that does not have some connection to moral duty (Moon, 2005, p. 215). Namely, religion is not simply a personal choice or preference. It is deeply rooted, and tied to the individual's social or cultural membership. It shapes the individual's understanding of himself and the world (Moon, 2005 , p. 219). Religious beliefs belong to fundamental convictions through which their holders retain a sense of their moral integrity and decency as people, and are so important to people that we can observe them as a part of their identity. However, "the notion of conscience refers also to a person's innermost normative beliefs; those that constitute his or her personal identity". If something touches on central personal principles, it is a matter of conscience (Sapir \& Statman, 2005, p. 472). Of course, not all innermost normative beliefs are religious, and nonreligious people have their own set of convictions. This concept of conscience is "essentially individual and subjective" (Sapir \& Statman, 2005, p. 473). Therefore, it is not possible to clearly divide the FoR and the freedom of conscience. That is why Chiassoni sees FoR as the specification of the liberal freedom of thought and the liberal freedom of conscience in relation to religious matters (Chiassoni, 2016). Despite the similarities between religious freedoms and other liberties, the enforcement of religious freedoms is frequently complicated by the distinctive relationship religion holds with the larger society (Finke, 2013, p. 310).

This brings us to the question, why is the violation of freedom of conscience that occurs when FoR is violated more disturbing - and therefore requires greater protection - than the violation of freedom of conscience in other contexts (Sapir \& Statman, 2005, pp. 476, 477)? Of course, there are answers to this question. McConnell (according to Sapir \& Statman, 2005, p. 477) answers that there is a difference between conscientious decisions whose source is religious and arise from subjugation to God's command (they lie outside man's range of control), and those whose source is not as they arise from voluntary choice. I find this answer inadequate because trying to answer the question regarding the strength of various convictions resembles the proverbial question about the number of angels that can stand on a tip of a needle - we do not know. But, one can argue that other - nonreligious beliefs - and their violation, did not cause such violent conflicts such as those caused by violations of FoR. Suppressing religious beliefs has 
DRUŠ. ISTRAŽ. ZAGREB GOD. 28 (2019), BR. 2, STR. 189-206

STANIČIĆ, F: DOES RELIGIOUS... a documented tendency to provoke violence and wars. Sometimes, "religious restrictions are justified as a necessity for curbing violence and maintaining public order, but research finds just the opposite. Social conflict is often a consequence of increased religious restrictions" (Finke, 2013, p. 306). Secondly, "religious freedoms serve to defuse potential violence and the increased restrictions are associated with increased violence. Restrictions often provide the very conditions needed for religious social conflicts to occur" (Finke, 2013, p. 310). That is why it is important to note that granting FoR special status is, often, in the public interest as it prevents strife and violent conflicts. There is strong empirical support for the proposition that human rights compliance in general, and religious freedom compliance in particular, expand the prospects for peace (Little, 2016, p. 1220; Grim \& Finke, 2011). Grim $\&$ Finke found that "violent religious persecution and conflict rise as government and social restrictions on religion increase (Grim \& Finke, 2011, p. 212). They have also demonstrated "the pacifying consequences of religious freedoms ... when social and government restrictions on religion are reduced, violent religious persecution is reduced" (Grim \& Finke, 2011, p. 210.). Again, I am not suggesting that FoR is an absolute right because of the "risk" argument. If you grant certain rights to religious groups, it is possible to antagonise secular society. That is why the state can limit FoR, for example, for the protection of public health, morals or for the protection of the rights and freedoms of others.

However, FoR has at least three aspects. It consists of freedom of religious belief, freedom of religious practice and the right not to be discriminated against. Contrasting FoR to freedom of expression is possibly the most important in this matter. We can see it as a "potential gag on expression" (Evans, 2014, p. 537) or one can see expression as a tool for "pedalling distressingly hurtful comments or attitudes" (Evans, 2014, p. 538). When we see the jurisprudence of the ECtHR, we can see that it found, in its Kokkinakis judgement, that the intersection of the FoR "and the freedom of expression constitutes a fact that both rights are of value and should be enjoyed to the fullest extent possible without negatively impacting the enjoyment of the rights of others" (Evans, 2014, pp. 543-544). This line of reasoning is also affirmed by the UN Human Rights Committee in its General Comment No. 34 on the freedom of expression: "Prohibitions or displays of lack of respect for a religion or other belief system, including blasphemy laws, are incompatible with the Covenant."

However, that is often not possible. Namely, the ECtHR recognises that the peaceful enjoyment of FoR "by adherents 
DRUŠ. ISTRAŽ. ZAGREB GOD. 28 (2019), BR. 2, STR. $189-206$

STANIČIĆ, F: DOES RELIGIOUS.. of religious faiths at the very least may justify a State in taking action against the dissemination of expression that is, in respect to objects of veneration, gratuitously offensive to others and profane." (Murdoch 2012, p. 71).

FoR is not an absolute right. Sometimes, the State has to balance the interests of individuals and society as a whole. Often, these two rights contradict each other. If we said that freedom of expression is a FHR, and the FoR is not, that would mean that, in the case of contradiction, it would have to give way to freedom of expression in every instance. I find this line of reasoning faulty. Namely, FoR is a powerful tool in defending minority rights. There has to be a "balancing of interests" and only in cases which would, according to the ECtHR, meet a "pressing social need", protecting the rights and freedoms of others, should the freedom of expression gain the upper hand regarding the FoR. This can also be seen as a way a struggle between religion and the secular may occur, which can also add tensions in a society. Therefore, the State and the ECtHR must make a choice of priorities (Tulkens, 2014, pp. 524-525). Careful line drawing is needed to ensure that the goal of pluralism is not defeated by the measure adopted (Murdoch, 2007, p. 52). The right to FoR takes precedence regarding the right of expression especially when the damage to religious minorities and their culture could be significant and direct. However, this still leaves the question whether this would apply if the price to be paid by the majority were high. Sapir \& Statman argue that it would not (2005, p. 484). If we observe the judgement S.A.S. v. France, we will see that the ECtHR adopted a new approach under which the limitation ground of "the rights and freedoms of others" now includes "respect for the minimum set of values in an open and democratic society", in particular vivre ensemble (S.A.S. v. France 2014, para. 121; Erlings, 2015). The US Supreme Court discussed a similar problem in several cases: Lyng v. Northwest Indian Cemetery Protective Association (485 U.S. 439 1988), Employment Division, Department of Human Resources of Oregon v. Smith (494 U.S. 872 1990), Lamb's Chapel v. Center Moriches Union Free School District (508 US 384 1993), Rosenberger v. Rector and Visitors of the University of Virginia (515 US 819 1995). The Court has held that religious expression can find protection under rules prohibiting "viewpoint" discrimination under the Free Speech Clause of the First Amendment, and the justices have sometimes preferred applying freedom of speech to freedom of religion. From the abovementioned, I conclude that FoR cannot be derived from freedom of expression. Also, the "right to culture" as drafted by Sapir (1999) is not recognised and does not cover all aspects of FoR because 
DRUŠ. ISTRAŽ. ZAGREB GOD. 28 (2019), BR. 2, STR. 189-206

STANIČIĆ, F.: DOES RELIGIOUS... it is limited to threats to "religious life, usually within a geographic area in which the religious minority represents a majority." (Sapir \& Statman 2005, p. 507).

If we observe closely, FoR cannot be derived (and protected) from freedom of association. According to the ECtHR's jurisprudence, FoR has precedence over the right of association. As ECtHR puts it, "religious communities traditionally and universally exist in the form of organised structures. Where the organisation of the religious community is at issue, Article 9 of the Convention must be interpreted in the light of Article 11. ... the right of believers to freedom of religion encompasses the expectation that the community will be allowed to function peacefully, free from arbitrary State intervention. The autonomous existence of religious communities is indispensable for pluralism in a democratic society and is an issue at the very heart of the protection which Article 9 affords. It directly concerns not only the organisation of these communities as such but also the effective enjoyment of the right to freedom of religion by all their active members. Were the organisational life of the community not protected by Article 9 , all other aspects of the individual's freedom of religion would become vulnerable..." (Sindicatul "Păstorul cel Bun" v. Romania 2013, para. 136).

In accordance with the principle of autonomy, the State is prohibited from obliging a religious community to admit new members or to exclude existing ones. Similarly, Article 9 of the Convention does not guarantee any right to dissent within a religious body; in the event of a disagreement over matters of doctrine or organisation between a religious community and one of its members, the individual's FoR is exercised through his freedom to leave the community (Sindicatul "Păstorul cel Bun" v. Romania 2013, para. 136). From this judgement one can see that the right to FoR and the right to association can come into conflict in which case FoR prevails over the freedom of association as ECtHR ruled in its practice.

Furthermore, putting the right to association on a higher level than FoR could cause a complete change of certain religious communities and their internal organisation, against their will. For example, how would the ban of ordaining women in the Catholic Church survive? Such a situation would result in a profound, obligatory change which the state would enforce (if there were women who wanted to be ordained and objected that their right to association was being violated).

Associations have to implement democratic interior structure. Some religions do not recognise the right of its members to a democratic structure. If the state were to make 
DRUŠ. ISTRAŽ. ZAGREB GOD. 28 (2019), BR. 2, STR. $189-206$

STANIČIĆ, F: DOES RELIGIOUS.. such religions change their internal structure, it is clear that the affected religious community would oppose such action. Such considerations are likely to cause strife in society, especially between its secular and religious forces, and on the other hand, harder rapprochement of various religious groups defending their rights, thus causing further rift between the secular and religious parts of society.

In order to further demonstrate that FoR cannot be derived from other FHRs, I would like to give an example of one right that is considered "usual" and is widely observed. Without acknowledging FoR the status of a FHR, one could not protect that right calling on other FHRs such as the right to expression, conscience or association. The right in question is the right not to work on a religious holiday. It does not matter whether we take Christmas, Eid al-Fitr, Hanuka or some other great religious holiday, the members of a religion who live in a society where FoR constitutes a FHR, have the right to demand that they are exempt from work on that day. This right cannot be derived from other FHRs as it is clearly religious in origin.

"By the seventh day God completed His work which He had done, and He rested on the seventh day from all His work which He had done. Then God blessed the seventh day and sanctified it, because in it He rested from all His work which God had created and made." (Genesis 2:2,3).

One could claim that this right could be drawn from the right to conscience (like, for example, conscientious objection regarding military service), but I would nevertheless point out that, one can, within their rights, claim that military service is against their philosophical convictions and invoke the right of conscience (although this right is "covered" by freedom of religion as it is a "precious tool for atheists, agnostics, sceptics and those who do not have any relation towards faith"). It is true, as I stated supra, that the right of conscience and FoR are the most difficult to separate. However, I find that freedom of conscience cannot be used to request exemption from work on some day as any individual could make another request and the freedom of conscience does not stretch that far, as religion is not simply a personal choice or preference, which conscience can be. If we acknowledged that this right could be drawn from freedom of conscience, then every individual would be entitled to request not to work on any given day, claiming that their conscience demands it.

We can clearly see that not all aspects of FoR can possibly be derived, and protected, through other more "basic" rights. Therefore, FoR deserves special status as a FHR in its own right. 
Some scholars argue, using various arguments, that FoR does not warrant special protection. Among those arguments I found that the one regarding FoR as a derived right is most interesting and most valid for research. If FoR could really be derived from more basic rights, there would be no justification for awarding it such high legal status. That is why I compared FoR with other FHRs from which it could perhaps be derived and protected. I argue that it cannot be derived (protected) from other FHRs such as freedom of conscience, expression and association even when put together. As I have previously ruled out the "non-existence of God" argument and the "breach of equality" argument, FoR should be protected as a FHR. Religious freedoms "rely on the same institutions as other human rights for support and protection, but religions hold distinctive and complex relationships with the state and the larger culture" (Finke, 2013, p. 310). Of course, this does not mean that FoR is absolute. The ECtHR's case law is abundant in this regard (Dahlab v. Switzerland 2001; Kalaç v. Turkey 1997; X X v. the United Kingdom 1978; S.A.S. v. France). It is the duty of the State to make a decision balancing the interests of all involved and the public interest.

\section{REFERENCES}

Binderup, L. (2007). Liberal equality - from minority rights to the limits of tolerance. In L. Binderup, \& T. Jensen (Eds.), The Rights and Plights of Religious Minorities (pp. 95-109). Odense: University of Southern Denmark.

Chiassoni, P. (2016). Protecting freedom of conscience in a constitutional state. Diritto e questioni pubbliche, 16(2), 21-50.

Dworkin, R. (2013). Religion without God. Harvard: Harvard University Press.

Erlings, E. (2015). The Government did not refer to it: SAS v France and Orde Public at the European Court of Human Rights. Melbourne Journal of International Law, 16(2), 3-22.

European Court of Human Rights, Research division (2013). Overview of the Court's case law on freedom of religion, Council of Europe. Available at http://www.echr.coe.int/Documents/Research_report_ religion_ENG.pdf

Evans, M. D. (2014). And should the first be last? Brigham Young University Law Review, 3, 531-546.

Finke, R. (2013). Origins and consequences of religious freedoms: A global overview. Sociology of Religion, 74(3), 297-313. https://doi.org/ 10.1093/socrel/srt011

Grim, B. J., \& Finke, R. (2011). The price of freedom denied: Religious persecution and conflict in the twenty-first century. Cambridge: Cambridge University Press.

Harari, Y. N. (2014). Sapiens: A brief history of humankind. Signal: McClelland \& Stewart. 
DRUŠ. ISTRAŽ. ZAGREB GOD. 28 (2019), BR. 2, STR. 189-206

STANIČIĆ, F. DOES RELIGIOUS..

Himma, K. E. (2014). Why religious freedom does not warrant protection by a special right. Available at http://papers.ssrn.com/sol3/papers.cfm? abstract_id $=2635930$.

Horwitz, P. (2014). A troublesome right: The 'law' in Dworkin's treatment of law and religion. Boston University Law Review, 94(4), 1225-1240.

Leiter, B. (2008). Why tolerate religion. Constitutional Commentary, 25(1), $1-27$.

Leiter, B. (2013). Why tolerate religion. Princeton: Princeton University.

Little, D. (2016). Human rights, religious freedom, and peace. Brigham Young University Law Review, 1, 1215-1235.

Moon, R. (2005). Religious commitment and identity: Syndicat Northcrest v. Amselem. Supreme Court Law Review, 29, 201-220.

Murdoch, J. (2007). Freedom of thought, conscience and religion. Council of Europe. Available at https://rm.coe.int/168007ff4f

Murdoch, J. (2012). Protecting the right to freedom of thought conscience and religion under the European Convention on Human Rights. Strasbourg: Council of Europe.

Raz, J. (1986). The morality of freedom. Oxford: Clarendon Press.

Rawls, J. (1999). A theory of justice. Cambridge: Harvard University Press.

Sapir, G. (1999). Religion and state: A fresh theoretical start. Notre Dame Law Review, 75(2), 579-652.

Sapir, G., \& Statman, D. (2005). Why freedom of religion does not include freedom from religion. Law and Philosophy, 24(5), 467-508. https://doi.org/10.1007/s10982-004-2895-8

Smith, S. D. (1991). The rise and fall of religious freedom in constitutional discourse. University of Pennsylvania Law Review, 140(1), 149-240. https://doi.org/10.2307/3312322

Smith, S. D. (2014). The rise and decline of American religious freedom. Harvard: Harvard University Press.

Sparer, E. (1984). Fundamental human rights, legal entitlements, and the social struggle: A friendly critique of the critical legal studies movement. Stanford Law Review, 36(1/2), 509-574. https://doi.org/10. 2307/1228691

Strong, S. I. (2015). Religious rights in historical, theoretical and international context: Hobby Lobby as a jurisprudential anomaly? Vanderbilt Journal of Transnational Law, 48(3), 813-889.

Strong, S. I. (2017). Transforming religious liberties: A new theory of religious rights for national and international law systems. Cambridge: Cambridge University Press. https://doi.org/10.1017/9781316832097

Tiedemann, P. (2015). Is there a human right to freedom of religion? Human Rights Review 16(2), 83-98. https://doi.org/10.1007/s12142-014$0342-2$

Tulkens, F. (2014). Freedom of religion under the European convention on human rights: A precious asset. Brigham Young University Law Review, 3, 509-530.

White, R., \& Overy, C. (2006). The European convention on human rights. 
DRUŠ. ISTRAŽ. ZAGREB GOD. 28 (2019), BR. 2, STR. 189-206

STANIČIĆ, F.: DOES RELIGIOUS...

\section{Zahtijeva li vierska sloboda zaštitu kao temelino ljudsko pravo?}

\section{Frane STANIČIĆ}

Pravni fakultet, Zagreb

Sloboda vjeroispovijedi je u mnogim pravnim dokumentima navedena kao temeljno pravo. Europska konvencija o ljudskim pravima propisuje da svatko ima pravo na slobodu mišljenja, savjesti i vjeroispovijedi. Kada pregledamo ustave država zapadnoga pravnog kruga, nalazimo da je u većini njih propisana sloboda vjeroispovijedi kao temelino pravo. Međutim, ima autora koji smatraju da sloboda vjeroispovijedi ne zaslužuje zaštitu kao posebno pravo. Nijhov je glavni argument taj da se pravo na slobodu vjeroispovijedi može izvesti iz drugih, osnovnijih, prava i da bi se to pravo trebalo štititi kroz zaštitu takvih prava. Cili je ovog rada odrediti zavrjeđuje li sloboda vjeroispovijedi zaštitu kao temeljno pravo ili bi trebala biti zaštićena kao izvedeno pravo, u kojem bi slučaju trebalo biti zaštićeno kroz zaštitu drugih temeljnih prava, kao što su pravo na slobodu savjesti.

Ključne riječi: sloboda vjeroispovijedi, temeljno pravo, izvedeno pravo, pravna zaštita

\section{(c) (i) (5)}

Međunarodna licenca / International License:

Imenovanje-Nekomercijalno/ Attribution-NonCommercial 